\title{
PRETERM BIRTH AND FETAL GROWTH RESTRICTION IN HIV-INFECTED BRAZILIAN PREGNANT WOMEN
}

Helena Lucia Barroso DOS REIS(1), Karina da Silva ARAUJO(2), Lilian Paula RIBEIRO(2), Daniel Ribeiro DA ROCHA(2), Drielli Petri ROSATO(2), Mauro Romero Leal PASSOS(3) \& Paulo Roberto MERÇON DE VARGAS(4)

\begin{abstract}
SUMMARY
Introduction: Maternal HIV infection and related co-morbidities may have two outstanding consequences to fetal health: motherto-child transmission (MTCT) and adverse perinatal outcomes. After Brazilian success in reducing MTCT, the attention must now be diverted to the potentially increased risk for preterm birth (PTB) and intrauterine fetal growth restriction (IUGR). Objective: To determine the prevalence of PTB and IUGR in low income, antiretroviral users, publicly assisted, HIV-infected women and to verify its relation to the HIV infection stage. Patients and Methods: Out of 250 deliveries from HIV-infected mothers that delivered at a tertiary public university hospital in the city of Vitória, state of Espírito Santo, Southeastern Brazil, from November 2001 to May 2012, 74 single pregnancies were selected for study, with ultrasound validated gestational age (GA) and data on birth dimensions: fetal weight (FW), birth length (BL), head and abdominal circumferences (HC, AC). The data were extracted from clinical and pathological records, and the outcomes summarized as proportions of preterm birth (PTB, $<37$ weeks), low birth weight (LBW, $<2500 \mathrm{~g})$ and small (SGA), adequate (AGA) and large (LGA) for GA, defined as having a value below, between or beyond the $\pm 1.28 \mathrm{z} / \mathrm{GA}$ score, the usual clinical cut-off to demarcate the $10^{\text {th }}$ and $90^{\text {th }}$ percentiles. Results: PTB was observed in $17.5 \%$, LBW in $20.2 \%$ and SGA FW, BL, HC and AC in $16.2 \%, 19.1 \%, 13.8 \%$, and $17.4 \%$ respectively. The proportions in HIV-only and AIDS cases were: PTB: 5.9 versus $27.5 \%$, LBW: $14.7 \%$ versus $25.0 \%$, SGA BW: $17.6 \%$ versus $15.0 \%$, BL: $6.0 \%$ versus $30.0 \%$, HC: $9.0 \%$ versus $17.9 \%$, and AC: $13.3 \%$ versus 21.2\%; only SGA BL attained a significant difference. Out of 15 cases of LBW, eight (53.3\%) were preterm only, four (26.7\%) were SGA only, and three (20.0\%) were both PTB and SGA cases. A concomitant presence of, at least, two SGA dimensions in the same fetus was frequent. Conclusions: The proportions of preterm birth and low birth weight were higher than the local and Brazilian prevalence and a trend was observed for higher proportions of SGA fetal dimensions than the expected population distribution in this small casuistry of newborn from the HIV-infected, low income, antiretroviral users, and publicly assisted pregnant women. A trend for higher prevalence of PTB, LBW and SGA fetal dimensions was also observed in infants born to mothers with AIDS compared to HIV-infected mothers without AIDS.
\end{abstract}

KEYWORDS: Pregnancy; HIV; Infant; Preterm birth; Fetal weight; Low birth weight; Small for gestational age.

\section{INTRODUCTION}

The main consequences of maternal HIV infection to fetal health are mother-to-child transmission (MTCT) and the potentially increased risk of adverse pregnancy outcomes. The timely diagnosis and the provision of free antiretroviral therapy (ART) reduced $\mathrm{MTCT}^{12}$ in Brazil. Attention must now be paid to the potentially increased risk for preterm birth (PTB) and intrauterine fetal growth restriction (IUGR).

PTB and IUGR are the most determining factors of perinatal morbidity and mortality all over the world ${ }^{13,33}$, which are also more related to neonatal complications ${ }^{50,59}$, poor postnatal growth ${ }^{5,22,23}$, and diseases whose consequences may extend to late adulthood ${ }^{3}$, with the burden of the high cost of prolonged surveillance and intervention ${ }^{18}$.
The relationship between these adverse outcomes and the intrauterine exposure to HIV and to antiretroviral treatment remains controversial and unresolved. It is unknown if PTB and IUGR result from a direct effect of the virus, from the immunosuppression, from associated co-morbidities or from non-HIV associated factors ${ }^{4}$. Antiretroviral therapy use has also been suggested as a possible risk factor ${ }^{19,38}$.

The reported prevalence of PTB and IUGR in infants born to HIVinfected mothers is variable and inconsistent ${ }^{29,46}$. This may be due to several reasons, including inappropriate assessment of gestational age (GA), lack of a standardized definition and assessment of IUGR, and the absence of adjustment for confounding factors ${ }^{4,13}$. The difficulty of obtaining precise information on GA has resulted in the use of low birth weight $(\mathrm{LBW})$ as a proxy for IUGR in some studies ${ }^{46}$. In many places, the

(1) Gynecologist and Obstetrics of Cassiano Antonio Moraes University Hospital, Health Sciences Centre, Federal University of Espírito Santo.

(2) Graduate Medical Student, Health Sciences Centre, Federal University of Espírito Santo.

(3) Obstetrician and Professor of the Materno-fetal Health Postgraduate Course of Fluminense Federal University, Niteroi, Rio de Janeiro State, Brazil.

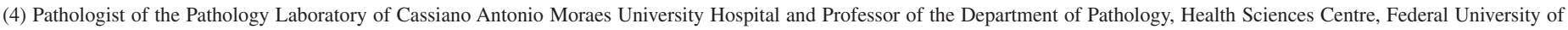
Espírito Santo, Vitória, Espírito Santo, Brazil

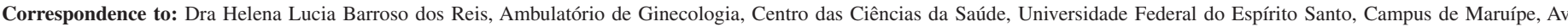
Marechal Campos 1468, 29043-900 Maruípe, Vitória, ES, Brasil. E-mail: hbarroso@intervip.com.br 


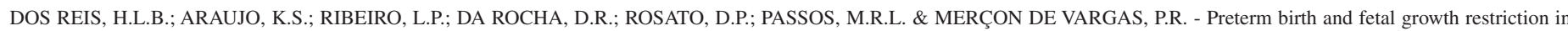
HIV-infected Brazilian pregnant women. Rev. Inst. Med. Trop. Sao Paulo, 57(2): 111-20, 2015.

same social and behavioral risk factors related to HIV-infection, preterm birth and IUGR may be shared by the same women, resulting in a high prevalence of these adverse outcomes ${ }^{50}$.

In this scenario, it is necessary to know the local reality in order to face the challenge. The city of Vitória has a population of about 327,081 with a 0.856 human development index, the lowest infant mortality rate in Brazil (7.93 : 1000) with a perinatal component of $65.7 \%{ }^{56}$ and a $63.0 \%$ fetal death proportion ${ }^{39}$. However, as in other places, there is high income distribution disparity and limited access to high quality healthcare ${ }^{41}$. From 1997 to 2001, the prevalence rate of HIV-infection in pregnant women was $0.41 \%$, which was similar to the mean Brazilian rate ${ }^{52}$. The $3.1 \%$ MTCT rate was also similar to the 2.7 to $8.6 \%$ prevalence rates reported for $\mathrm{Brazil}^{38,47,52}$.

Most of the published Brazilian studies have focused on gestational HIV-infection prevalence and on the MTCT rate with less attention paid to PTB and IUGR prevalence and associated outcomes. Therefore, the aim of this study was to determine the prevalence of PTB and of fetal growth disturbances in a public tertiary referral maternity unit for low income, HIV-infected women who are taking ART, as well as to verify its relation to the HIV infection stage.

\section{PATIENTS AND METHODS}

This is a case series observational and analytic study conducted at Cassiano Antonio Moraes University Hospital (HUCAM), a 314-bed tertiary public hospital in the city of Vitória, state of Espírito Santo, Southeastern Brazil. The HUCAM is one of the three regional referral centers for the treatment and care of HIV-infected patients, with an annual mean of 1500 deliveries.

Data were retrieved from HUCAM records for all 250 deliveries of HIV-infected pregnant women that occurred between November 2001 and May 2012. From this data, gestations that met all the following criteria were selected for study: known maternal HIV-infection diagnosis, singleton pregnancy, a minimum of 22 gestational weeks confirmed by an ultrasound examination before 22 weeks, and an adequate set of maternal and fetal biometrical data suitable for fetal growth analysis. One twin pregnancy was excluded, as were cases with missing ultrasound data or unavailable clinical records. In the studied period, one woman had two gestations and the remaining women had only one, totaling 74 gestations from 73 women for the study.

The study protocol was approved by the Institutional Review Board. As a retrospective survey of records, informed signed consent was not required, but access to patients' records was obtained from institutional and Public Health Authorities. All women and their children received the standard obstetrical and neonatal care. Strict confidentiality was adhered to regarding any data collected throughout the study.

Data on maternal, pregnancy and neonatal characteristics including infant HIV status during pediatric follow-up were collected from medical, obstetrical, neonatal and laboratory institutional records as well as the State Health Secretariat public reports. The data were extracted in a structured form, entered and analyzed in an Excel sheet (Microsoft Office 2010, Microsoft Corporation, USA) formatted to calculate the GA and to analyze the fetal dimensions and growth.
The diagnosis of HIV infection was based on the Brazilian National AIDS Program guidelines, with the following considered as positive indicators: a positive sample by ELISA screening, with confirmation by Western blot or indirect fluorescence reaction, and HIV infection diagnosis by Rapid Tests ${ }^{11}$. An HIV infection was classified as AIDS according to the current modified Centers for Disease Control and Prevention (CDC) criteria and the Rio de Janeiro-Caracas (1992) criteria and/or a documented medical AIDS diagnosis ${ }^{11}$. Children exposed to HIV were followed and those with two positive HIV DNA polymerase chain reaction (PCR) tests were classified as HIV-infected; a child with at least one negative DNA PCR test after the age of two months or a negative HIV-antibody test after the age of 18 months was classified as uninfected ${ }^{11}$. The medication type, duration, and beginning of use were combined to describe the multiclass ART used by each woman, during each week of gestation. A medication was considered as taken if used for at least five uninterrupted weeks. The beginning of use was classified according to the critical fetal growth period as either before 16 weeks (including before pregnancy), between 16 and 28 weeks or after 28 weeks of gestation.

Maternal BMI was classified according to WHO criteria ${ }^{58}$ and HIV-associated co-morbidity was ascertained according to the Rio de Janeiro-Caracas criteria ${ }^{11}$.

The GA at birth was expressed in exact days of gestation, calculated from the last menstrual period if confirmed by ultrasound examination before 22 weeks, using the last menstrual period estimate in cases with a discrepancy of up to seven days; otherwise the ultrasound estimate was used ${ }^{43,44}$. In cases of fetal deaths, the GA at death was calculated by subtraction of the intrauterine retention time estimated by anatomicpathological criteria ${ }^{28}$ from the calculated GA at birth. PTB was defined as delivery at less than 37 weeks of gestation, and very PTB as less than 34 weeks of gestation. Major fetal congenital malformation includes potentially lethal abnormalities or those that will require immediate postnatal surgery ${ }^{57}$.

Neonatal dimensions (birth weight (BW), birth length (BL), head (HC) and abdominal (AC) circumferences) were measured within 24 hours of birth by neonatal doctors or nurses. In fetal death cases, the autopsy dimensions were used. Low birth weight (LBW) was defined as less than 2,500 grams, macrosomia as more than 3,999 grams and normal weight as anything between these two values.

To compare the various fetal dimensions, regardless of the GA at birth, all fetal dimensions were converted to z-scores for gestational age (z/GA score), using published fetal normative reference values for weight ${ }^{25}, \mathrm{BL}^{17}, \mathrm{HC}^{15}$, and $\mathrm{AC}^{16}$, re-expressed as proportional growth curves $^{25,26,27}$ and adjusted for location, term of pregnancy, neonatal measurement, and population median value at 40 weeks as has been recently recommended ${ }^{7,26,32,40}$. For birth length, the fetal length was estimated by femur diaphyseal length using the Hadlock formula ${ }^{30}$ and the proportional growth curve was elaborated with the Chitty fetal femur length growth curve ${ }^{17}$. For the local values, the birth weight (3458 $\pm 415 \mathrm{~g})$, length $(495 \pm 23 \mathrm{~mm})$, head $(350 \pm 15 \mathrm{~mm})$ and abdominal circumference $(325 \pm 20 \mathrm{~mm}$ ) values at 277 to 284 days ( 40 weeks) from 273 singleton (male and female), non-malformed, live births in the city of Vitória from middle and high-income women between 2008 and 2013 were taken. The reference values for fetal weight $(\mathrm{FW})$ were further adjusted for maternal race, weight, height, parity and fetal gender ${ }^{25}$ and 


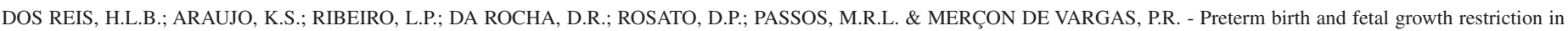
HIV-infected Brazilian pregnant women. Rev. Inst. Med. Trop. Sao Paulo, 57(2): 111-20, 2015.

$\mathrm{BL}^{30}$ and $\mathrm{HC}$ for fetal sex only ${ }^{48}$. Each fetal dimension was categorized as small (SGA), adequate (AGA) and large (LGA) for GA, defined as having a z/GA value below, between or beyond the $\pm 1.28 \mathrm{z} / \mathrm{GA}$ score, the usual clinical cut-off to demarcate the $10^{\text {th }}$ and $90^{\text {th }}$ percentiles. Venn diagrams were used to analyze the combining distribution of the PTB, LBW and categorized fetal growth assessments.

Statistical analysis. Cases with missing data for a variable were excluded from the analysis of that specific variable. The available data from excluded cases were compared with the included cases. For categorical data, frequency distributions and corresponding 95\% confidence intervals $(95 \% \mathrm{CI})$ were calculated. For continuous variables, a standard descriptive statistical analysis was performed, including the calculation of the arithmetic mean and standard deviation, median, quartiles and range as well as the distribution depicted as box-plots ${ }^{31}$.
The proportions of observed growth disturbances categories (SGA, AGA, and LGA), were compared with the expected values $(10 \%, 80 \%$, and $10 \%)$, taking the reference value distribution as a control group ${ }^{14}$. The quantitative contrasts between groups' proportions were analyzed by direct increment ${ }^{24}$, and by chi-square test statistics with a bicaudal 0.05 significance value; the Fisher exact test was used if the expected count for a cell table was less than 5 .

\section{RESULTS}

Casuistry, maternal, gestational and perinatal characteristics, and outcome. The 74 cases studied amount to $26.6 \%$ of HUCAM and $6.6 \%$ of all Espírito Santo State maternal HIV-infected deliveries in the studied period. Maternal demographic, clinical, obstetrical and perinatal details and outcomes are shown in Tables 1 and 2.

Table 1

Sociodemographic, behavioral, and medical characteristics

\begin{tabular}{|c|c|c|c|}
\hline & \multicolumn{2}{|c|}{ Included cases } & \multirow{2}{*}{$\begin{array}{c}\text { Excluded cases } \\
\text { All } \\
\text { F/N }(\%)\end{array}$} \\
\hline & $\begin{array}{c}\text { HIV } \\
\text { F/N }(\%)^{\mathrm{a}} \\
\end{array}$ & $\begin{array}{c}\text { AIDS } \\
\text { F/N }(\%) \\
\end{array}$ & \\
\hline \multicolumn{4}{|l|}{ Demographic } \\
\hline Maternal age - less than 20 years & $3 / 34(8.8 \%)$ & $1 / 40(2.5 \%)$ & $18 / 172(10.4 \%)$ \\
\hline Maternal age - more than 35 years & $3 / 34(8.8 \%)$ & $7 / 40(17.5 \%)$ & $13 / 172(7.5 \%)$ \\
\hline Ethnicity - non-white & $28 / 34(82.3 \%)$ & $28 / 40(70.0 \%)$ & $115 / 150(76.6 \%)$ \\
\hline Instruction - illiterate or less than 5 years & $9 / 34(26.4 \%)$ & $10 / 40(25.0 \%)$ & $15 / 35(42.8 \%)$ \\
\hline Instruction -5 to 8 years & $11 / 34(32.3 \%)$ & $10 / 40(25.0 \%)$ & $13 / 35(37.1 \%)$ \\
\hline Occupation - housewife & $20 / 33(60.6 \%)$ & $23 / 40(57.5 \%)$ & $84 / 105(80.0 \%)^{\mathrm{b}}$ \\
\hline Marital status - unmarried & $3 / 31(9.6 \%)$ & $8 / 39(20.5 \%)$ & $14 / 32(43.7 \%)^{\mathrm{b}}$ \\
\hline Residency outside Vitoria City & $25 / 34(73.5 \%)$ & $27 / 40(67.5 \%)$ & $90 / 160(56.2 \%)^{\mathrm{b}}$ \\
\hline \multicolumn{4}{|l|}{ Obstetrical history } \\
\hline Primiparity & $10 / 34(29.4 \%)$ & $8 / 40(20.0 \%)$ & $8 / 34(23.5 \%)$ \\
\hline Multiparity - 3 or more & $10 / 34(29.4 \%)$ & $10 / 40(25.0 \%)$ & $10 / 34(29.4 \%)$ \\
\hline Previous abortion & $11 / 34(32.3 \%)$ & $13 / 40(32.5 \%)$ & $8 / 34(23.5 \%)$ \\
\hline Previous perinatal death & $4 / 34(11.7 \%)$ & $3 / 40(7.5 \%)$ & $1 / 34(2.9 \%)$ \\
\hline \multicolumn{4}{|l|}{ Current pregnancy } \\
\hline Prenatal care $-<6$ attendances & $7 / 33(21.2 \%)$ & $10 / 40(25.0 \%)$ & $37 / 63(58.7 \%)^{\mathrm{b}}$ \\
\hline Prenatal care - not in HUCAM & $21 / 34(61.7 \%)$ & $19 / 40(47.5 \%)$ & $35 / 61(57.3 \%)$ \\
\hline Body mass index $-<18.5$ & $3 / 34(8.8 \%)$ & $4 / 38(10.5 \%)$ & $4 / 31(12.9 \%)$ \\
\hline Body mass index $-25<\mathrm{BMI}<30$ & $6 / 34(17.6 \%)$ & $9 / 40(22.5 \%)$ & $6 / 31(19.3 \%)$ \\
\hline Body mass index - BMI > 29.9 & $4 / 34(11.7 \%)$ & $1 / 40(2.5 \%)$ & $2 / 31(6.4 \%)$ \\
\hline Smoking - any & $4 / 34(11.7 \%)$ & $7 / 39(17.9 \%)$ & $16 / 34(47.0 \%)^{b}$ \\
\hline Alcohol abuse & $2 / 34(5.8 \%)$ & $0 / 40(0.0 \%)$ & $7 / 35(20.0 \%)^{\mathrm{b}}$ \\
\hline Illicit drug use & $2 / 34(5.8 \%)$ & $1 / 40(2.5 \%)$ & $7 / 35(20.0 \%)^{b}$ \\
\hline Maternal anemia & $6 / 32(18.7 \%)$ & $5 / 38(13.1 \%)$ & $10 / 31(32.2 \%)$ \\
\hline Hypertension (any type) & $4 / 33(12.1 \%)$ & $5 / 40(12.5 \%)$ & $3 / 32(9.3 \%)$ \\
\hline Urinary tract infection & $7 / 33(21.2 \%)$ & $6 / 40(15.0 \%)$ & $5 / 31(16.1 \%)$ \\
\hline Diabetes mellitus & $1 / 33(3.0 \%)$ & $0 / 40(0.0 \%)$ & $0 / 34(0.0 \%)$ \\
\hline Syphilis & $1 / 33(3.0 \%)$ & $1 / 40(2.5 \%)$ & $5 / 31(16.1 \%)^{\mathrm{b}}$ \\
\hline HSV infection & $0 / 33(0.0 \%)$ & $2 / 38(5.2 \%)$ & $1 / 34(2.9 \%)$ \\
\hline HPV infection (condiloma acuminatum) & $2 / 32(6.2 \%)$ & $3 / 38(7.8 \%)$ & $3 / 33(9.0 \%)$ \\
\hline
\end{tabular}

a: number refers to absolute frequency $(\mathrm{F})$ of category, number of cases with data $(\mathrm{N})$ and relative frequency $(\%)$; b: $p<0.05$ on chi square or Fisher exact test between included versus excluded cases; $\mathbf{c}: p<0.05$ on chi square or Fisher exact test between HIV versus AIDS cases; non-significant contrast not flagged. 
DOS REIS, H.L.B.; ARAUJO, K.S.; RIBEIRO, L.P.; DA ROCHA, D.R.; ROSATO, D.P.; PASSOS, M.R.L. \& MERÇON DE VARGAS, P.R. - Preterm birth and fetal growth restriction in HIV-infected Brazilian pregnant women. Rev. Inst. Med. Trop. Sao Paulo, 57(2): 111-20, 2015.

Table 2

Labor, perinatal outcome and HIV infections details

\begin{tabular}{|c|c|c|c|}
\hline & \multicolumn{2}{|c|}{ Included cases } & \multirow{2}{*}{$\begin{array}{c}\text { Excluded cases } \\
\text { All } \\
\text { F/N }(\%) \\
\end{array}$} \\
\hline & $\begin{array}{c}\text { HIV } \\
\text { F/N }(\%)^{\mathrm{a}} \\
\end{array}$ & $\begin{array}{c}\text { AIDS } \\
\text { F/N }(\%) \\
\end{array}$ & \\
\hline \multicolumn{4}{|l|}{ Labor and perinatal outcome } \\
\hline Labour - spontaneous & $12 / 34(35.2 \%)$ & $13 / 40(32.5 \%)$ & $16 / 34(47.0 \%)$ \\
\hline Labour - none & $19 / 34(55.8 \%)$ & $26 / 40(65.0 \%)$ & $18 / 34(52.9 \%)$ \\
\hline Rupture of Membranes - spontaneous & $6 / 33(18.1 \%)$ & $8 / 39(20.5 \%)$ & $9 / 34(26.4 \%)$ \\
\hline Caesarian delivery & $26 / 34(76.4 \%)$ & $37 / 40(92.5 \%)^{\mathrm{c}}$ & $109 / 155(70.3 \%)^{\mathrm{b}}$ \\
\hline Fetal sex - female & $22 / 34(64.7 \%)$ & $19 / 40(47.5 \%)$ & $77 / 154(50.0 \%)$ \\
\hline Gestational age - mean $\pm \mathrm{s}$ (days) & $267 \pm 19$ & $262 \pm 24$ & $263 \pm 25$ \\
\hline Gestational age - median (IQR) & $271(266-275)$ & $271(263-273)$ & $271(260-278)$ \\
\hline Preterm birth - less than 37 weeks & $2 / 34(5.9 \%)$ & $11 / 40(27.5 \%)^{\mathrm{c}}$ & $22 / 92(23.9 \%)$ \\
\hline Birth weight - mean \pm sd (grams) & $2939 \pm 715$ & $2717 \pm 751$ & $2840 \pm 684$ \\
\hline Birth weight - median (IQR) (grams) & $2950(2669-3339)$ & $2893(2519-3169)$ & $2900(2550-3280)$ \\
\hline Low birth weight - less than 2500 grams & $5 / 34(14.7 \%)$ & $10 / 40(25.0 \%)$ & $36 / 157(22.9 \%)$ \\
\hline Apgar score - less than 7 in first minute & $1 / 33(3.0 \%)$ & $1 / 39(2.5 \%)$ & $13 / 150(8.6 \%)$ \\
\hline Need for intensive neonatal care & $7 / 32(21.8 \%)$ & $11 / 39(28.2 \%)$ & $5 / 32(15.6 \%)$ \\
\hline Major congenital anomalies & $0 / 34(0.0 \%)$ & $2 / 40(5.0 \%)$ & $0 / 35(0.0 \%)$ \\
\hline ToRCH infection - syphilis & $1 / 74(2.9 \%)$ & $1 / 40(2.5 \%)$ & - \\
\hline ToRCH infection - toxoplasmosis & $0 / 74(0.0 \%)$ & $1 / 40(2.5 \%)$ & - \\
\hline Fetal death & $1 / 34(2.9 \%)$ & $1 / 40(2.5 \%)$ & $2 / 172(1.1 \%)$ \\
\hline Neonatal death & $0 / 34(0.0 \%)$ & $1 / 40(2.5 \%)$ & $3 / 172(1.7 \%)$ \\
\hline \multicolumn{4}{|l|}{ HIV infection details } \\
\hline HIV diagnosis prior to current pregnancy & $15 / 34(44.1 \%)$ & $36 / 41(87.8 \%)^{\mathrm{c}}$ & $22 / 35(62.8 \%)$ \\
\hline HIV status of sexual partner - positive & $13 / 23(56.5 \%)$ & $13 / 27(48.1 \%)$ & $12 / 20(60.0 \%)$ \\
\hline Cases with AIDS defining features & - & $40 / 74(54.1 \%)$ & $70 / 119(58.8 \%)$ \\
\hline Viral load - 1000 to 10000 copies & $8 / 24(33.3 \%)$ & $6 / 39(15.3 \%)$ & $6 / 25(24.0 \%)$ \\
\hline Viral load - more than 10000 copies & $4 / 24(16.6 \%)$ & $8 / 39(20.5 \%)$ & $6 / 25(24.0 \%)$ \\
\hline
\end{tabular}

a: number refers to absolute frequency $(\mathrm{F})$ of category, number of cases with data $(\mathrm{N})$ and relative frequency $(\%)$; $\mathbf{b}: p<0.05$ on chi square or Fisher exact test between included versus excluded cases; $\mathbf{c}: p<0.05$ on chi square or Fisher exact test between HIV versus AIDS cases; non-significant contrast not flagged.

HIV infection. HIV infection was diagnosed before the current pregnancy in $68.9 \%$ of cases and during antenatal care in $31.1 \%$ of cases. AIDS cases amounted to $40(54.1 \%)$ of the cases. Among cases with data, $28.8 \%(19 / 66)$ had a CD4 count of less than 350 cells $/ \mathrm{mm}^{3}(10.6 \%$ less than 200 cells $\left./ \mathrm{mm}^{3}\right)$, and $19.0 \%(12 / 63)$ had higher than 10,000 viral load copies $/ \mathrm{mL}$. Out of 54 children with at least 18 months of postnatal follow-up, there was no MTCT of HIV; no data were available about the 20 other children.

Perinatal outcome. The cesarean delivery rate was $85.1 \%$, without variation in the studied period. There was one neonatal death and two major fetal congenital malformations, all three from AIDS cases.

Antiretroviral therapy. According to ART use criteria (being used for at least five uninterrupted weeks of gestation), the lack of use of any ART during gestation was observed in five of the 74 cases $(6.8 \%)$. Of the 69 gestations in which ART was used, 24 (34.8\%) started ART prior to the current gestation, $11(15.9 \%)$ started between one and 15 weeks, 30 (43.5\%), between 16 and 28 weeks, and four (5.8\%) between 29 weeks and delivery; intrapartal zidovudine was used in $95.7 \%$ cases. One-drug ART was used in six $(8.7 \%)$ of the cases, two-drug therapy in one $(1.4 \%)$, and a three or more drug therapy (HAART) in 62 (89.9\%); $56(90.3 \%)$ out of the 62 HAART users took a protease inhibitor, of which $19(30.6 \%)$ took the protease inhibitor drug during the whole gestation. Therapy drug switch was observed in nine $(13.0 \%)$ of the 69 cases.

Gestational age. The mean GA for all cases was 264 (37 weeks and 6 days) \pm 22 days, but was five days lower for the AIDS cases. The overall PTB rate was $17.5 \%$ (95\% CI: 0 to $38.3 \%$ ) (Table 3), higher in AIDS cases; the very preterm birth (less than 34 weeks) rate was $10.8 \%$ without significant difference between AIDS and HIV-only cases; no post-term delivery was observed. A comparison between the included and the excluded cases regarding PTB revealed similarity, but there was a significant difference between the AIDS and HIV-only cases (Table 2).

Fetal growth disturbances. The distribution of fetal growth disturbances in all cases and according to HIV infection status (HIVonly and AIDS) is shown in Figure 1 and in Table 3. The median birth 


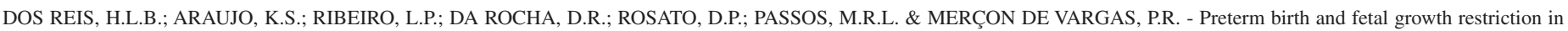
HIV-infected Brazilian pregnant women. Rev. Inst. Med. Trop. Sao Paulo, 57(2): 111-20, 2015.

Table 3

Distributions of gestational age, absolute and z score value of fetal dimensions, and proportions of preterm births, low birth weight and small for gestational age

\begin{tabular}{|c|c|c|c|c|}
\hline Variable & $\begin{array}{c}\text { All } \\
\text { cases }\end{array}$ & $\begin{array}{l}\text { HIV } \\
\text { cases }\end{array}$ & $\begin{array}{l}\text { AIDS } \\
\text { cases }\end{array}$ & \\
\hline Gestational age (days) - n & 74 & 34 & 40 & \\
\hline mean \pm sd & $264 \pm 22$ & $267 \pm 20$ & $262 \pm 23$ & \\
\hline median (interquartile range) & $271(265-275)$ & $271(266-277)$ & $271(263-274)$ & \\
\hline$<34$ weeks - F $(\%)^{\mathrm{a}}$ & $8(10.8 \%)$ & $2(5.8 \%)$ & $6(15.0 \%)$ & $\mathrm{ns}$ \\
\hline$<37$ weeks - F $(\%)$ & $13(17.5 \%)$ & $3(8.8 \%)$ & $10(25.0 \%)$ & $\mathrm{ns}$ \\
\hline Fetal weight (grams) - n & 74 & 34 & 40 & \\
\hline mean $\pm \mathrm{sd}$ & $2819 \pm 738$ & $2939 \pm 715$ & $2717 \pm 751$ & \\
\hline median (interquartile range) & $2915(2595-3232)$ & $2950(2669-3339)$ & $2893(2518-3169)$ & \\
\hline $\mathrm{z} / \mathrm{GA}$ score - mean $\pm \mathrm{sd}$ & $-0.40 \pm 1.37$ & $-0.23 \pm 1.49$ & $-0.55 \pm 1.26$ & \\
\hline$<2500$ grams & $15(20.2 \%)$ & $5(14.7 \%)$ & $10(25.0 \%)$ & $\mathrm{ns}$ \\
\hline SGA - F (\%) & $12(16.2 \%)$ & $6(17.6 \%)$ & $6(15.0 \%)$ & $\mathrm{ns}$ \\
\hline Fetal length $(\mathrm{mm})$ - n & 73 & 33 & 40 & \\
\hline mean \pm sd & $466 \pm 40$ & $478 \pm 26$ & $456 \pm 47$ & \\
\hline median & $470(460-485)$ & $475(460-490)$ & $470(444-485)$ & \\
\hline $\mathrm{z} / \mathrm{GA}$ score - mean $\pm \mathrm{sd}$ & $-0.55 \pm 1.28$ & $-0.19 \pm 1.00$ & $-0.86 \pm 1.14$ & \\
\hline SGA - F (\%) & $14(19.1 \%)$ & $2(6.0 \%)$ & $12(30.0 \%)$ & $*$ \\
\hline Head circumference $(\mathrm{mm})-\mathrm{n}$ & 72 & 33 & 39 & \\
\hline mean \pm sd & $335 \pm 30$ & $339 \pm 21$ & $330 \pm 36$ & \\
\hline median & $340(330-350)$ & $340(335-350)$ & $340(330-348)$ & \\
\hline $\mathrm{z} / \mathrm{GA}$ score - mean $\pm \mathrm{sd}$ & $-0.28 \pm 1.32$ & $-0.20 \pm 1.00$ & $-0.35 \pm 1.54$ & \\
\hline SGA - F (\%) & $10(13.8 \%)$ & $3(9.0 \%)$ & $7(17.9 \%)$ & $\mathrm{ns}$ \\
\hline Abdominal circumference (mm) - n & 63 & 30 & 33 & \\
\hline mean \pm sd & $303 \pm 40$ & $307 \pm 27$ & $300 \pm 49$ & \\
\hline median & $310(295-330)$ & $308(300-320)$ & $310(290-330)$ & \\
\hline $\mathrm{z} / \mathrm{GA}$ score - mean $\pm \mathrm{sd}$ & $-0.40 \pm 2.03$ & $-0.41 \pm 1.13$ & $-0.39 \pm 2.62$ & \\
\hline SGA - F (\%) & $11(17.4 \%)$ & $4(13.3 \%)$ & $7(21.2 \%)$ & ns \\
\hline
\end{tabular}

a: number refers to absolute frequency $(\mathrm{F})$ of category, number of cases with data $(\mathrm{N})$ and relative frequency $(\%)$. $*: p<0.05$ on chi square test between HIV versus AIDS cases; non-significant contrast not flagged.

weight was 57 grams higher in HIV-only cases compared to AIDS cases. LBW was observed in $20.2 \%$ (95\% CI: 11.1 to $29.5 \%$ ) of cases, with a higher non-significant proportion (25.0\% versus $14.7 \%)$ in AIDS than in HIV-only cases. Fetal macrosomia was observed in one HIV-only case.

The mean BW z/GA score was $-0.40 \pm 1.37$ (all cases), -0.55 (AIDS), and -0.23 (HIV-only) cases. SGA BW was found in $16.2 \%$ (95\% CI: 7.8 to $24.6 \%$ ) of cases without significant difference between HIV-only and AIDS cases ( $17.6 \%$ versus $15.0 \%$ ); among the 12 SGA birth weight three $(25.0 \%)$ were preterm. LGA BW was found in $6.8 \%(95 \% \mathrm{CI}$ : 1.1 to $12.5 \%$ ) of cases, occurring in all but one of the HIV-only cases. LBW and SGA BW were not significantly more frequent in cases with mothers that were smokers compared to those that were non-smokers ( $9.1 \%$ versus $9.7 \%$ and $9.1 \%$ versus $17.7 \%$, respectively).

The mean BL z/GA score was $-0.55 \pm 1.27$ (all cases), -0.19 (HIVonly), and -0.86 (AIDS). The median birth length was $5 \mathrm{~mm}$ lower in AIDS than HIV-only cases (Table 3) but a SGA BL was found in $19.1 \%$ (95\% CI: 10.0 to 27.8 ) of cases, with a higher significant rate in AIDS cases $(30.0 \%$ versus $6.0 \%)$. LGA BL was found in $4.1 \%$ of cases $(95 \%$ CI: 0 to $8.6 \%$ ), all in HIV-only cases.

The mean head circumference $\mathrm{z} / \mathrm{GA}$ score was slightly reduced with a mean of $-0.28 \pm 1.32$ (all cases), -0.20 (HIV-only), and -0.35 (AIDS). A SGA HC was observed in $13.8 \%$ (95\% CI: 8.9 to $26.3 \%$ ) of cases with a higher, but not significantly, rate in AIDS than in HIV-only cases $(17.9 \%$ versus $9.0 \%$ ). LGA HC was observed in nine (12.2\%, 95\% CI: 4.7 to $19.7 \%$ ) cases, five in AIDS cases. The mean abdominal circumference $\mathrm{z} /$ GA score was also slightly reduced with a mean of $-0.40 \pm 2.03$ without significant difference between HIV-only and AIDS cases. A SGA AC was observed in $11(17.4 \%, 95 \%$ CI: 0 to $40.0 \%)$ cases and a LGA AC in five $(6.8 \%, 95 \%$ CI: 1.1 to $12.5 \%)$ cases. Neither the SGA nor LGA AC proportion differed between AIDS and HIV cases.

Combining distribution of PTB and growth restriction. Out of 15 cases of LBW, eight (53.3\%) were preterm only, four $(26.7 \%)$ were SGA only, and three $(20.0 \%)$ were both PTB and SGA cases. Out of the 63 cases with all four fetal dimensions available, the combined 


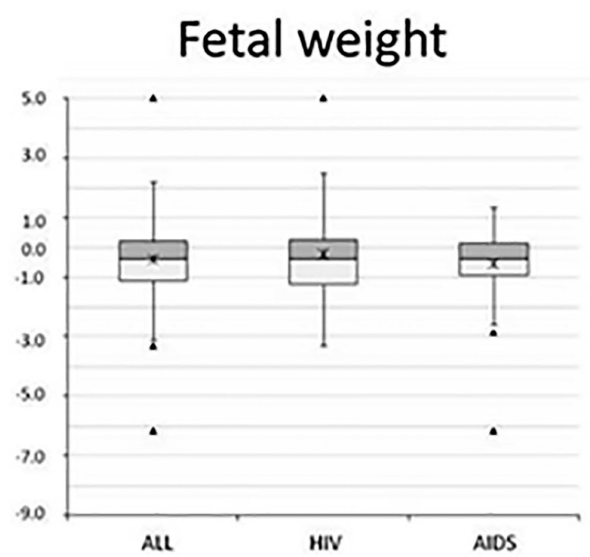

Head circumference

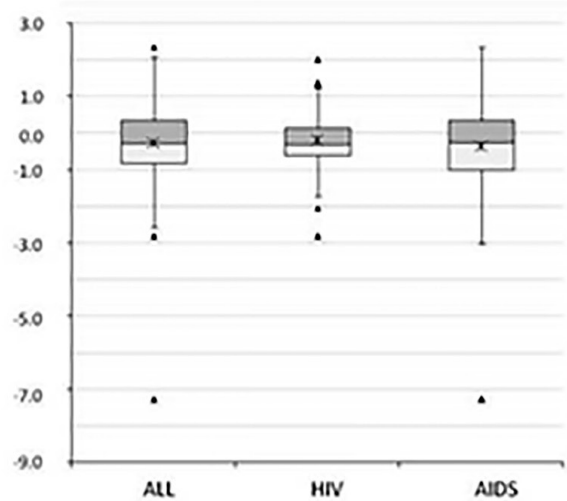

Birth lenght

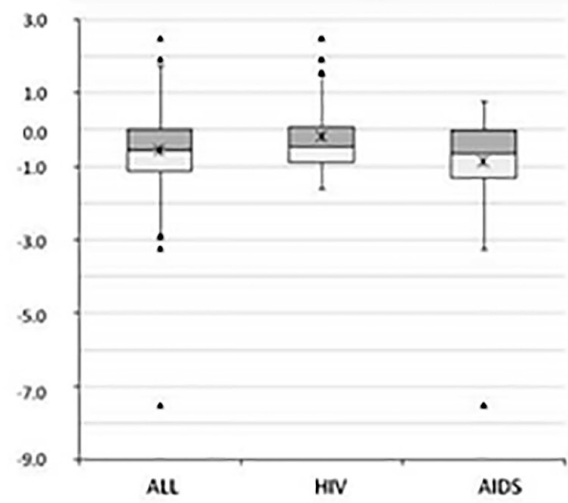

Abdominal circumference

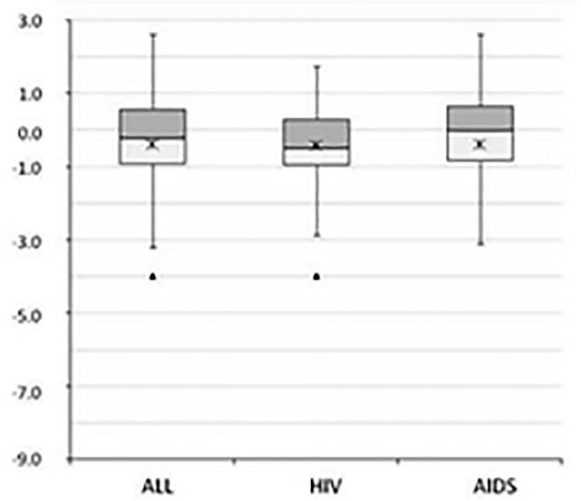

ALL: All cases studied (HIV only and AIDS cases); HIV: HIV only cases; AIDS: AIDS cases.

Fig. 1 - Distribution of z-score for gestational age of fetal dimensions.

distribution was analyzed by Venn diagram (not shown) and revealed that $24(38.1 \%)$ cases had, at least, one SGA dimension, $11(17.5 \%)$ at least two, 13 (20.6\%) only one, seven (11.1\%) only two, and two (3.2\%) all four SGA fetal dimensions. Out of the 12 SGA BW, 50\% were also SGA BL and SGA AC.

\section{DISCUSSION}

The HIV-infected women assisted at HUCAM come from the local community, mainly from outside the metropolitan area of the city of Vitória. Due to the study design, case selection was made from a tertiary hospital and there was a strict requirement for ultrasound validated GA estimation, the representativeness of casuistry cannot be assured. A comparison between included and excluded cases regarding the available demographic and clinical details (Tables 1 and 2) reveals similarity in maternal age, ethnicity, instruction, parity, previous abortion, AIDS, PTB birth and LBW proportions, but the included cases have significantly more women residing outside the area of the city of Vitória and significantly fewer cases of housewives, unmarried women, alcohol, illegal drug and tobacco users, low antenatal attendance, syphilis in current pregnancy, and cesarean delivery so a selection bias could not be excluded from cases with a lower risk of adverse outcomes. However, HIV-only cases did not differ significantly from AIDS cases regarding any demographics and behavioral and medical characteristics (Table 2). Moreover, the demographics and clinical characteristics of the studied cases were similar to other local studies ${ }^{41}$ and likely represent the poor pregnant women of the large metropolitan areas of Brazil. The fact that $68.9 \%$ of the mothers knew their HIV status before pregnancy highlights the need for education in order to minimize the disease's burden.

The $17.5 \%$ PTB rate observed in this study was higher than that reported for the general population of developed countries (5.0 to $7.0 \%)^{35}$, Brazil (3.4 to $\left.15.0 \%\right)^{51}$, and the state of Espírito Santo $(4.8 \%)^{10}$. Furthermore, it was similar to the prevalence reported in HIV-infected pregnancies in Europe $(14.7 \text { to } 16.0 \%)^{9,53}$, Africa $(13.3 \text { to } 21,8 \%)^{46,54}$ and Brazil $(11.5 \text { to } 18.2 \%)^{36,32}$, as well as the prevalence reported for the USA (17.0 to $19.9 \%)^{49,19}$. A non-significant trend for a higher proportion of PTB in AIDS cases, compared with HIV-only cases was observed.

In this study, compared to the expected population distribution (10\%), the BW z/GA score had a shift towards lower values and the proportion of SGA BW was higher, clearly indicating some fetal growth restriction in the children of HIV-infected women. The results of this investigation are similar to those reported by FAUSTO et al..$^{23}$, in a cohort of 130 full-term 


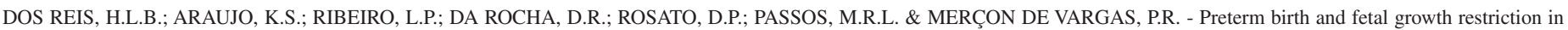
HIV-infected Brazilian pregnant women. Rev. Inst. Med. Trop. Sao Paulo, 57(2): 111-20, 2015.

infants in Belo Horizonte, state of Minas Gerais: mean BW z/GA score of $-0.52 \pm 0.88$ for the non-infected and $-0.83 \pm 1.11$ for the infected infants, without statistically significant differences between both groups. Although they do not report the SGA proportion, there is a clear shift towards lower values. The finding of an increased proportion of SGA $\mathrm{BW}$ in infants of HIV-positive mothers in this investigation accords with previous studies in Africa ${ }^{46,54}$, but was lower than the $31.2 \%$ reported by AARON et al. in the USA ${ }^{1}$.

Likewise, the observed $20.2 \%$ prevalence of LBW was higher than the 10 to $18 \%$ for developed countries ${ }^{19}$, the $9.0 \%$ for population-based Brazilian studies $^{51}$, and for the $6.6 \%$ of SINASC-ES ${ }^{10}$. However, it was similar to the reported proportion in Europe ${ }^{9}$, the $\mathrm{USA}^{7}$, Africa ${ }^{54}$, and Brazilian HIV-infected women ${ }^{37}$. LBW may be due to PTB, SGA or both $^{22}$. In developed countries, where LBW rates are low, it is caused mainly by PTB whereas in developing countries, where the prevalence is high, LBW is often due to IUGR ${ }^{6,34}$. In the casuistry of this study, $26.7 \%$ of LBW were due to SGA alone, $53.3 \%$ to PTB alone and $20.0 \%$ to both PTB and SGA BW. Previous reports of more LBW in AIDS than in non-AIDS cases $^{21,36}$ could not be confirmed.

Little attention has been paid to the temporal and the compartmental frames of fetal growth, that is, the timing at which each fetal organ has its maximum growth and is more vulnerable to growth disturbance. As the various risk factors may act at different moments of intrauterine life they may have different effects on different fetal organs ${ }^{20}$. The distribution of SGA affecting fetal compartments other than BW has rarely been reported. The observed proportion of SGA BL in babies born to HIV-infected mothers agrees with some $\mathrm{e}^{5,45}$ but not all studies ${ }^{29}$. HC is an important parameter to assess, because the brain is the last and least affected organ in fetal deprivation ${ }^{15}$; a reduced $\mathrm{HC}$ was reported in some studies $^{2,45}$, but not confirmed in others ${ }^{29}$. Conversely, the AC, reflecting the fetal liver and abdominal subcutaneous mass, ${ }^{16}$ is the most sensitive and early affected dimension in IUGR; a report of AC analysis in infants of HIV-infected mothers could not be found.

Despite the presence of only $11(17.5 \%)$ cases with at least two concomitant SGA fetal dimensions, it was found that $50 \%$ of the 12 cases with SGA BW also have SGA BL or SGA AC, pointing to a split distribution of symmetric and asymmetric types of BW growth restriction. Only one report pointing to an early effect of HIV infection on fetal growth ${ }^{21}$ could be found.

The relative contribution of HIV and non-HIV-infection risk factors to adverse perinatal outcomes has not been well defined. Maternal poverty, lack of social support, risk behaviors such as tobacco and illegal drug use, medical and gestational diseases such as anemia, diabetes, hypertension, among others, are well-known risk factors for PTB and IUGR in both non-HIV-infected and HIV-infected women ${ }^{18}$. Such factors could add to HIV-infection and related conditions (such as high viral load, immunosuppression, HIV-associated infections and ART), increasing the risk of PTB and poor fetal growth. Therefore, it is difficult to separate the independent roles of the non-HIV associated factors from those more directly related to HIV in PTB and IUGR determination ${ }^{8}$. In this study, the following tendency was observed: a higher prevalence of PTB, LBW and SGA BW, BL, HC, and AC in infants born to HIV-infected mothers with AIDS compared with those born to non-AIDS mothers. However, due to the small casuistry, it was not possible to explore the role of the severity of HIV infection or its complex interaction with non-HIV comorbidity and specific ART in PTB and fetal growth determination. Larger studies are necessary to solve this issue ${ }^{13}$.

There are many reasons for the discrepancy in reported HIV-infection related prevalence of PTB and IUGR. Firstly, few studies have used adequate estimates of $\mathrm{GA}^{13,19,44}$. A systematic review of Brazilian PTB prevalence found only one out of twelve population-based studies using an early ultrasound validated GA estimate ${ }^{51}$. The compliance with that requirement in casuistry of low income publicly assisted women may explain the huge case exclusion in this study.

Secondly, the mean is not an adequate indicator of growth disorders. Besides, comparing the observed mean with a local control group could be misleading because such a control group may not adequately reflect a normal population. However, even without a difference between HIVexposed and non-exposed fetuses (or in HIV-only versus AIDS cases, as shown in the present study), a significant difference in SGA proportions of growth disturbances could emerge from comparison between the study group and reference distribution, the true "control group"14.

Thirdly, the lack of a standardized definition of IUGR ${ }^{13}$, and the use of a non-representative reference norm ${ }^{7,40,43,55}$ limit comparability between studies ${ }^{40,7}$. As the references for birth dimensions underestimate the preterm growth compared with a fetal reference ${ }^{32}$, a hybrid fetal and neonatal growth curve adjusted to local median term neonatal dimensions should be used ${ }^{7,25,40}$. Furthermore, any available population reference does not account for within-population variations attributable to maternal height, weight, parity and fetal gender, known factors that may affect fetal growth ${ }^{26,27}$ for which the customized or individualized reference has been proposed ${ }^{26,27,40}$. The decision of what reference to adopt affects the growth categorization and the prevalence of growth disorders ${ }^{1}$. There is no published growth study either employing that approach in Brazil, or using fetal rather than birth weight reference standard in HIV-infected women.

Lastly, it is difficult to discriminate the role of HIV-infection on fetal growth from the numerous and geographically variable proportion of others risk factors ${ }^{13,50}$. To add complexity, the association of these risk factors leads to the existence of multiple possible groups, which would demand a larger number of cases to allow a detailed analysis.

Limitations of this study. The exclusion of many cases due to missing records and data accounts for an inaccurate representation of the overall local or national HIV-infected mothers. This is a typical issue of the health care contradiction of low-income people in Brazil: regardless of the open access to healthcare and the high proportion of prenatal attendance and hospital delivery, there is evidence of poor quality care ${ }^{42}$ such as many instances of non-compliance with standard care, lack of access to and delay in delivering complementary exam results. Besides, the poor quality, loss of, and hindrance in accessing patients' records explain, for instance, the lack of explicit records of cesarean delivery. However, in spite of the huge exclusion, no significant difference regarding $\mathrm{PBW}$ or LBW rate was observed.

Due to the small casuistry, a multivariate analysis and adjustment for specific ARV regimen and for important risk factors such as smoking, hypertension and anemia in the PTB and IUGR determination could not be performed. Also, it was not possible to address the potential effects of 
DOS REIS, H.L.B.; ARAUJO, K.S.; RIBEIRO, L.P.; DA ROCHA, D.R.; ROSATO, D.P.; PASSOS, M.R.L. \& MERÇON DE VARGAS, P.R. - Preterm birth and fetal growth restriction in HIV-infected Brazilian pregnant women. Rev. Inst. Med. Trop. Sao Paulo, 57(2): 111-20, 2015.

different ARV schemes in gestation, with or without protease inhibitor (PI), that are not clearly established ${ }^{9,19,49,54}$. However, as the majority of patients were already using ARV, the longer exposure to ARV could explain the higher proportion of adverse fetal outcomes in this study.

Finally, a serial fetal growth assessment, as recommended and clinically employed with symphysis-fundal height ${ }^{26}$ and ultrasound measurements ${ }^{44}$, was not made. Indeed, a true growth study demands demonstration of a reduced growth velocity along with the gestation. However, the study was limited to a few adequate sets of timely ultrasound measurements of fetal dimensions.

Larger and multicenter natural history studies of HIV-infected cohorts of pregnant women are necessary to provide more definite answers regarding the relationship between HIV infection, co-morbidity, ART use, and preterm birth and fetal growth disorders. Despite the small sample size and these limitations, the authors believe the results of this study are important because of the scarcity of Brazilian reported studies on PTB and IUGR prevalence in HIV-infected women. Moreover, they emphasize the need for prenatal, at birth and postnatal growth monitoring to identify infants with suboptimal growth and to ensure appropriate care and treatment, in order to improve their clinical course, quality of life and prospects.

\section{CONCLUSION}

This study found a high prevalence of preterm birth, low birth weight and small gestational age, fetal weight, length, head and abdominal circumferences associated with HIV-infected, ART using, low-income and publicly assisted Brazilian women. A trend for higher prevalence of PTB, LBW and SGA fetal dimensions in infants born to AIDS compared with non-AIDS mothers was observed.

\section{CONFLICTS OF INTEREST}

The authors declare none.

\section{RESUMO}

\section{Nascimento pré-termo e restrição de crescimento fetal em gestantes brasileiras infectadas pelo HIV}

Introdução: A infecção materna pelo HIV e comorbidades associadas podem ter duas consequências para a saúde fetal, a transmissão vertical e o desfecho perinatal adverso. Após o sucesso em reduzir a transmissão vertical, deve-se dar atenção ao risco potencial de nascimento pretermo (PRT) e de restrição de crescimento fetal (RCF). Objetivo: Determinar a prevalência de PRT e RCF em gestantes de baixa renda, infectadas pelo HIV, usuárias de terapia antirretroviral atendidas em hospital público terciário e verificar sua relação com o estágio da infecção viral. Casuística e métodos: Dentre os 250 partos de gestantes infectadas pelo HIV, ocorridos em um hospital universitário na cidade de Vitória, estado do Espírito Santo, Sudeste do Brasil, entre novembro de 2001 e maio de 2012, foram selecionadas 74 gestações não-gemelares, com idade gestacional confirmada por ultrassonografia e as dimensões neonatais: peso ao nascer $(\mathrm{PN})$, comprimento $(\mathrm{CN})$ e perímetros cefálico $(\mathrm{PC})$ e abdominal (PA). Os dados foram extraídos dos prontuários clínicos e laboratoriais e o desfecho sumarizado como nascimento pretermo (PRT
$<37$ semanas), baixo peso ao nascer (BPN $<2500$ g) e como pequeno (PIG), adequado (AIG) e grande (GIG) para a IG, definido como tendo um menor valor, entre e maior que $\pm 1.28 \mathrm{z} / \mathrm{IG}$ escore, o critério clínico usual para demarcar os percentis 10 e 90 . Resultados: PRT foi observado em $17,5 \%$, BPN em 20,2\% e PN, CN, PC e PA PIG em 16,2\%, 19,1\%, $13,8 \%$ e $17,4 \%$, respectivamente. As respectivas proporções observadas nos casos de HIV e AIDS foram: PRT: 5,9 versus 27,5\%, BPN: 14,7\% versus $25,0 \%$, PFN PIG: $17,6 \%$ versus $15,0 \%, \mathrm{CN}: 6,0 \%$ versus $30,0 \%$, PC: $9,0 \%$ versus $17,9 \%$ e PA: $13,3 \%$ versus $21,2 \%$; somente a diferença de CN PIG foi estatisticamente significativa. Dentre 15 neonatos com BPN, oito $(53,3 \%)$ eram somente PRT, quatro $(26,7 \%)$ PIG somente e três (20,0\%) PRT e PIG. Concomitância no mesmo caso de pelo menos duas dimensões PIG foi observada frequentemente. Conclusão: A proporção de baixo peso ao nascer foi maior que a prevalência local e brasileira e foi observada uma tendência para maior proporção de dimensões fetais PIG que a distribuição populacional esperada nesta pequena casuística de filhos de gestantes infectadas pelo HIV, usuárias de antirretrovirais, de baixa renda e assistidas em hospital público terciário. Observou-se também tendência para maior prevalência de PTR, BPN e dimensões fetais PIG em recém-nascidos de mães com AIDS comparados com os de mães infectadas por HIV sem AIDS.

\section{ACKNOWLEDGMENTS}

The authors would like to acknowledge the contribution of many current and former medical students for help with chart extraction of clinical, ultrasound and pathological data. For some clinical and epidemiological data, special acknowledgment is given to the contributions of Dr. Guilhermina Maria Soares Rabbi, from the Epidemiological Unit of Espírito Santo University Hospital, Dr. Sandra Fagundes from the Espírito Santo State Health Secretariat, Professor Dr. Geisa Baptista de Barros from the Pediatric Department of the Espírito Santo Federal University, Professor Dr. Angelica Espinosa Miranda, from the Department of Social Medicine of Espírito Santo Federal University, and the anonymous reviewers who made important suggestions to improve this paper.

\section{AUTHORS' ROLES}

Merçon de Vargas PR and Reis HLB participated in the conception and design of the study, as well as the drafting of the article. Merçon de Vargas PR, Reis HLB, Rosato DP, Rocha DR, Araujo KS and Ribeiro LP participated in the acquisition, analysis and interpretation of data. Merçon de Vargas PR, Reis HLB and Passos MRL contributed in the critical revisions of important intellectual content and final approval of the version to be published; all authors gave constructive comments during the writing and interpretation of results and substantially contributed to and approved the final manuscript.

\section{REFERENCES}

1. Aaron E, Bonacquisti A, Mathew L, Alleyne G, Bamford LP, Culhane JF. Small-forgestational-age births in pregnant women with HIV, due to severity of HIV disease, not antiretroviral therapy. Infect Dis Obstet Gynecol. 2012;2012:135030.

2. Banda Y, Chapman V, Goldenberg RL, Chi BH, Vermund SH, Stringer JS. Influence of body mass index on pregnancy outcomes among HIV-infected and HIV-uninfected Zambian women. Trop Med Int Health. 2007;12:856-61. 
3. Barker DJ. The developmental origins of adult disease. Eur J Epidemiol. 2003;18:733-6.

4. Baroncelli S, Tamburrini E, Ravizza M, Pinnetti C, Dalzero S, Scatà M, et al. Pregnancy outcomes in women with advanced HIV infection in Italy. AIDS Patient Care STDS 2011;25:639-45

5. Barros FC, Victora CG, Matijasevich A, Santos IS, Horta BL, Silveira MF. Preterm births, low birth weight, and intrauterine growth restriction in three birth cohorts in Southern Brazil: 1982, 1993 and 2004. Cad Saude Publica. 2008;24(Suppl 3):S390-8.

6. Belizán JM, Lechtig A, Villar J. Distribution of low-birth weight babies in developing countries. Am J Obstet Gynecol. 1978;132:704-5.

7. Bernstein IM, Mohs G, Rucquoi M, Badger GJ. Case for hybrid "fetal growth curves": a population-based estimation of normal fetal size across gestational age. J Matern Fetal Med. 1996;5:124-7

8. Birkhead GS, Pulver WP, Warren BL, Hackel S, Rodríguez D, Smith L. Acquiring human immunodeficiency virus during pregnancy and mother-to-child transmission in New York: 2002-2006. Obstet Gynecol. 2010;115:1247-55.

9. Boer K, Nellen JF, Patel D, Timmermans S, Tempelman C, Wibaut M, et al. The AmRo study: pregnancy outcome in HIV-1-infected women under effective highly active antiretroviral therapy and a policy of vaginal delivery. BJOG. 2007;114:148-55.

10. Brasil. Ministério da Saúde. Secretaria de Vigilância em Saúde. Banco de dados do Sistema de Informações sobre Nascidos Vivos (SINASC), 1994 a 2010. Brasília: MS/SVS; 2011 .

11. Brasil. Ministério da Saúde. Secretaria de Vigilância em Saúde. Departamento de Vigilância Epidemiológica. Guia de vigilância epidemiológica. $7^{\text {a }}$ ed. Brasília: Ministério da Saúde; 2009.

12. Brasil. Ministério da Saúde. Secretaria de Vigilância em Saúde. Recomendações para profilaxia da transmissão vertical do HIV e terapia anti-retroviral em gestantes. Brasília: Ministério da Saúde; 2010.

13. Brocklehurst $P$, French R. The association between maternal HIV infection and perinatal outcome: a systematic review of the literature and meta-analysis. Br J Obstet Gynaecol. 1998;105:836-48.

14. Cameron N, Preece MA, Cole TJ. Catch-up growth or regression to the mean? Recovery from stunting revisited. Am J Hum Biol. 2005;17:412-7.

15. Chitty LS, Altman DG, Henderson A, Campbell S. Charts of fetal size: 2. Head measurements. Br J Obstet Gynaecol. 1994;101:35-43.

16. Chitty LS, Altman DG, Henderson A, Campbell S. Charts of fetal size: 3. Abdominal measurements. Br J Obstet Gynaecol. 1994;101:125-31.

17. Chitty LS, Altman DG, Henderson A, Campbell S. Charts of fetal size: 4. Femur length. Br J Obstet Gynaecol. 1994;101:132-5.

18. Costello A, Francis V, Byrne A, Puddephatt C. Saving newborn lives: state of the world's newborns. Washington: Save the Children and Women \& Children First; 2001.

19. Cotter AM, Garcia AG, Duthely ML, Luke B, O’Sullivan MJ. Is antiretroviral therapy during pregnancy associated with an increased risk of preterm delivery, low birth weight, or stillbirth? J Infect Dis. 2006;193:1195-201.

20. Deter RL, Nazar R, Milner LL. Modified neonatal growth assessment score: a multivariate approach to the detection of intrauterine growth retardation in the neonate. Ultrasound Obstet Gynecol. 1995;6:400-10.

21. Dreyfuss ML, Msamanga GI, Spiegelman D, Hunter DJ, Urassa EJ, Hertzmark E, et al Determinants of low birth weight among HIV-infected pregnant women in Tanzania. Am J Clin Nutr. 200;74:814-26.
22. Euser AM, de Wit CC, Finken MJ, Rijken M, Wit JM. Growth of preterm born children Horm Res. 2008;70:319-28.

23. Fausto MA, Carneiro II M, Antunes CMF, Colosimo EA, Pinto JA. Longitudinal anthropometric assessment of infants born to HIV-1 infected mother, Belo Horizonte, Southeastern Brazil. Rev Saude Publica. 2011;45:652-60.

24. Feinstein AR. Principles of medical statistics. London: Chapman Hall; 2002.

25. Gardosi J, Mongelli M, Wilcox M, Chang A. An adjustable fetal weight standard. Ultrasound Obstet Gynecol. 1995;6:168-74.

26. Gardosi J. Customized fetal growth standards: rationale and clinical application. Semin Perinatol. 2004;28:33-40.

27. Gardosi J, Figueras F, Clausson B, Francis A. The customised growth potential: an international research tool to study the epidemiology of fetal growth. Paediatr Perinat Epidemiol. 2011;25:2-10.

28. Genest DR, Williams MA, Greene MF. Estimating the time of death in stillborn fetuses: I. Histologic evaluation of fetal organs; an autopsy study of 150 stillborns. Obstet Gynecol. 1992;80:575-84.

29. Habib NA, Daltveit AK, Bergsjø P, Shao J, Oneko O, Lie RT. Maternal HIV status and pregnancy outcomes in northeastern Tanzania: a registry-based study. BJOG. 2008;115:616-24.

30. Hadlock FP, Deter RL, Roecker E, Harrist RB, Park SK. Relation of fetal femur length to neonatal crown-heel length. J Ultrasound Med. 1984;3:1-3.

31. Hoaglin DC, Mosteler F, Tukey JW. Understanding robust and exploratory data analysis. New York: Willey; 2000.

32. Hutcheon JA, Platt RW. The missing data problem in birth weight percentiles and thresholds for "small-for-gestational-age". Am J Epidemiol. 2008;167:786-92.

33. Kim HY, Kasonde P, Mwiya M, Thea DM, Kankasa C, Sinkala M, et al. Pregnancy loss and role of infant HIV status on perinatal mortality among HIV-infected women. BMC Pediatr. 2012;12:138.

34. Kramer MS, Demissie K, Yang H, Platt RW, Sauvé R, Liston R. The contribution of mild and moderate preterm birth to infant mortality. JAMA. 2000;284:843-9.

35. Lawn JE, Cousens SN, Darmstadt GL, Bhutta ZA, Martines J, Paul V, et al. 1 year after The Lancet Neonatal Survival Series--was the call for action heard? Lancet. 2006;367(9521):1541-7.

36. Machado ES, Hofer CB, Costa TT, Nogueira SA, Oliveira RH, Abreu TF, et al. Pregnancy outcome in women infected with HIV-1 receiving combination antiretroviral therapy before versus after conception. Sex Transm Infect. 2009;85:82-7.

37. Melo VH, Aguiar RALP, Lobato ACL, Cavallo IKD, Kakehasi, FM, Romanelli, RMC, et al. Resultados maternos e perinatais de dez anos de assistência obstétrica a portadoras do vírus da imunodeficiência humana. Rev Bras Ginecol Obstet. 2005;27:683-90.

38. Menezes Succi RC. Mother-to-child transmission of HIV in Brazil during the years 2000 and 2001: results of a multi-centric study. Cad Saude Publica. 2007;23(Suppl 3):S379-89.

39. Merçon de Vargas PR. Avoidable infant and perinatal deaths? Lancet. 2000;356(Suppl):s13.

40. Mikolajczyk RT, Zhang J, Betran AP, Souza JP, Mori R, Gülmezoglu AM, et al. A global reference for fetal-weight and birthweight percentiles. Lancet. 2011;377(9780):185561.

41. Miranda AE, Soares RA, Prado BC, Monteiro RB, Figueiredo NC. Mother to child transmission of HIV in Vitória, Brazil: factors associated with lack of HIV prevention. AIDS Care. 2005; 17:721-8. 
DOS REIS, H.L.B.; ARAUJO, K.S.; RIBEIRO, L.P.; DA ROCHA, D.R.; ROSATO, D.P.; PASSOS, M.R.L. \& MERÇON DE VARGAS, P.R. - Preterm birth and fetal growth restriction in HIV-infected Brazilian pregnant women. Rev. Inst. Med. Trop. Sao Paulo, 57(2): 111-20, 2015.

42. Miranda AE, Rosetti Filho E, Trindade CR, Gouvêa GM, Costa DM, Ge Oliveira T, et al. Prevalência de sífilis e HIV utilizando testes rápidos em parturientes atendidas nas maternidades públicas de Vitória, Estado do Espírito Santo. Rev Soc Bras Med Trop. 2009;42:386-91.

43. Mongelli M, Gardosi J. Reduction of false-positive diagnosis of fetal growth restriction by application of customized fetal growth standards. Obstet Gynecol. 1996;88:844-8.

44. Mongelli M, Wilcox M, Gardosi J. Estimating the date of confinement: ultrasonographic biometry versus certain menstrual dates. Am J Obstet Gynecol. 1996;174(1 Pt 1):27881.

45. Moye J Jr, Rich KC, Kalish LA, Sheon AR, Diaz C, Cooper ER, et al. Natural history of somatic growth in infants born to women infected by human immunodeficiency virus. Women and Infants Transmission Study Group. J Pediatr.1996;128:58-69.

46. Ndirangu J, Newell ML, Bland RM, Thorne C. Maternal HIV infection associated with small-for-gestational age infants but not preterm births: evidence from rural South Africa. Hum Reprod. 2012;27:1846-56.

47. Nogueira SA, Abreu T, Oliveira R, Araújo L, Costa T, Andrade M, et al. Successful prevention of HIV transmission from mother to infant in Brazil using a multidisciplinary team approach. Braz J Infect Dis. 2001;5:78-86.

48. Olsen IE, Groveman SA, Lawson ML, Clark RH, Zemel BS. New intrauterine growth curves based on United States data. Pediatrics. 2010;125:e214-24.

49. Patel K, Shapiro DE, Brogly SB, Livingston EG, Stek AM, Bardeguez AD, et al. Prenatal protease inhibitor use and risk of preterm birth among HIV-infected women initiating antiretroviral drugs during pregnancy. J Infect Dis. 2010;201:1035-44.

50. Rollins NC, Coovadia HM, Bland RM, Coutsoudis A, Bennish ML, Patel D, et al. Pregnancy outcomes in HIV-infected and uninfected women in rural and urban South Africa. J Acquir Immune Defic Syndr. 2007;44:321-8.

51. Silveira MF, Santos IS, Barros AJ, Matijasevich A, Barros FC, Victora CG. Increase in preterm births in Brazil: review of population-based studies. Rev Saude Publica. 2008;42:957-64.
52. Szwarcwald CL, Barbosa Júnior A, Souza-Júnior PR, Lemos KR, Frias PG, Luhm KR, et al. HIV testing during pregnancy: use of secondary data to estimate 2006 test coverage and prevalence in Brazil. Braz J Infect Dis. 2008;12:167-72.

53. Townsend CL, Willey BA, Cortina-Borja M, Peckham CS, Tookey PA. Antiretrovira therapy and congenital abnormalities in infants born to HIV-infected women in the UK and Ireland, 1990-2007. AIDS. 2009;23:519-24.

54. Van der Merwe K, Hoffman R, Black V, Chersich M, Coovadia A, Rees H. Birth outcomes in South African women receiving highly active antiretroviral therapy: a retrospective observational study. J Int AIDS Soc. 2011;14:42.

55. Villar J, Altman DG, Purwar M, Noble JA, Knight HE, Ruyan P, et al. The objectives, design and implementation of the INTERGROWTH-21st project. BJOG. 2013;120(Suppl 2):9-26. doi:10.1111/1471-0528.12047.

56. Vitória. Estado do Espírito Santo. Secretaria da Saúde. Secretaria de Comunicação. Taxa de mortalidade infantil. [cited 2012 Nov 29]. Available from: http://www.vitoria. es.gov.br/secom.php?pagina $=$ noticias\&idNoticia $=8098$

57. Wigglesworth JS. Perinatal pathology. Philadelphia: W.B. Saunders;1984.

58. World Health Organization. Obesity: preventing and managing the global epidemic. Geneva:WHO; 2000. (Technical Report Series No. 894).

59. Zeitlin JA, Ancel PY, Saurel-Cubizolles MJ, Papiernik E. Are risk factors the same for small for gestational age versus other preterm births? Am J Obstet Gynecol. 2001;185:208-15.

Received: 5 April 2013

Accepted: 24 June 2014 